\title{
ARTUR JAZDON
}

\section{Karol Reyzner (1803-1887) - wydawca, księgarz i drukarz poznański}

STRESZCZENIE. Na przełomie lat trzydziestych i czterdziestych XIX wieku ożywił się poznański rynek książki. W czasie chwilowego złagodzenia założeń polityki państwa zaborczego wobec Polaków zaczęły powstawać wypożyczalnie i księgarnie polskie, publikujące po polsku i dla Polaków. Znacznie rozwinął się rynek prasy, zarówno gazet codziennych, jak i czasopism. Obok tak znanych wydawców jak Walenty Stefański, Jan K. Żupański, Napoleon Kamieński, Antoni Popliński, Ludwik Merzbach pojawił się Karol Reyzner. Nie odegrał tak znaczącej roli jak wymienieni nie publikował tak dużo i tak znakomitych dzieł jak oni. Funkcjonował jednak na rynku blisko pół wieku, tj. znacznie dłużej niż wielu innych ówczesnych wydawców. Wydając przede wszystkim książki dla ludu, bez ambicji naukowych i literackich, proste i tanie z punktu widzenia standardu edytorskiego, realizował istotną potrzebę społeczną. Artykuł omawia dzieje firmy, jej dorobek wydawniczy, skupia się także na scharakteryzowaniu działającej przy księgarni wypożyczalni - pierwszej prowadzonej przez Polaka i przeznaczonej dla Polaków. Analiza katalogów wypożyczalni pozwala wskazać, że - inaczej niż w przypadku działalności wydawniczej była ona skierowana do wyrobionego czytelnika, o czym świadczy wiele dzieł wartościowych, trudnych, autorstwa wybitnych literatów czy ówczesnych badaczy.

SŁOWA KLUCZOWE: Wielkopolska - XIX wiek; drukarstwo, księgarstwo, ruch wydawniczy - historia XIX wiek; czytelnictwo; wypożyczalnie książek - XIX wiek 
Od przełomu lat trzydziestych i czterdziestych XIX wieku datuje się w Poznaniu ożywienie ruchu wydawniczego, rozwój liczebny księgarń, wypożyczalni oraz potencjału poligraficznego. Zjawiska te nie doczekały się jednolitego, całościowego opracowania, choć wielu czołowym postaciom działającym na powyższych polach poświęcono indywidualne studia. Opisano dość dokładnie działalność wydawniczą Tytusa Działyńskiego, Edwarda Raczyńskiego, aktywność tak zasłużonych osób, jak Jana Konstantego Żupańskiego czy Walentego Stefańskiego, oraz instytucji - Drukarni i Księgarni Świętego Wojciecha, a także mniej znanych, np. Sylwestra Pawickiego. Przygotowywane jest opracowanie poświęcone Napoleonowi Kamieńskiemu, kolejnemu z wielkich ówczesnych wydawców i księgarzy. Wysiłki tych wybitnych osób i instytucji uzupełniane były działaniami innych, mniej znanych wydawców, księgarzy i drukarzy. Zaliczyć do tej grupy można Karola Reyznera. Długie lata funkcjonowania na rynku i jego aktywność zachęcaja aby przyjrzeć się bliżej pracy tego spolonizowanego Niemca, o którego działalności wydawniczej jedni powiedza, że „nie miała większego znaczenia”, gdyż wydawał głównie „pieśni religijne i druki o miernej wartości” ${ }^{1}$, inni zaś wskazywać będą „pionierską rolę” firmowanych przez niego druków².

Karol Jan Reyzner urodził się około 1803 roku w Poznaniu jako syn zawodowego żołnierza armii pruskiej Adama i Franciszki z Sieradzkich ${ }^{3}$. Niewiele wiemy o jego rodzinie, gdyż tylko nieoceniony Marceli Motty wspomina, że miał młodszego brata odznaczającego się „udaną i sympatyczną twarzą” oraz „szlachetniejszymi poczuciami i dążnością”, który po ukończeniu miejskiej szkółki chwycił się rzemiosła i pracował jako

${ }^{1}$ M. Walentynowicz, Wypożyczalnie ksiażek w Wielkim Księstwie Poznańskim, „Przegląd Historyczno-Oświatowy” 1960, nr 1, s. 5.

2 J. Prosnak, Zbiór Reyznera, „Muzyka” 1959, z. 3, s. 60.

3 J. Kozłowski, Reyzner Karol Jan, w: Wielkopolski słownik biograficzny, Poznań 1981, s. $621-622$. 
stolarz w Poznaniu, a następnie w kilku większych miastach niemiec$\mathrm{kich}^{4}$. Powróciwszy po paru latach do Poznania, założył własny warsztat; wyróżniał się niepospolitą biegłością w swoim zawodzie, przyzwoitością w życiu prywatnym i stosunkach z ludźmi oraz gorącym poczuciem patriotyzmu, czemu dał wyraz, angażując się w wydarzenia Wiosny Ludów. Według Mottego należał do „pierwszych tutaj rzemieślników polskich, którzy usiłowali wznieść się nad poziom tradycyjnego partactwa, a pod względem fachowym stanąć na równi z zagranicznymi przemysłowcami, jako też wypełniać przynależne obywatelskie i narodowe obowiązki" ${ }^{5}$. Można założyć, że chodzi o reklamującego się w latach czterdziestych w poznańskiej prasie stolarza Franciszka, który mieszkał

przy

ul.

Garbary 3, a prowadził zakład przy równoległej do Garbar ul. Klasztornej.

Przytoczono ten fragment dotyczący brata Karola, gdyż pokazuje on, że obaj Reyznerowie przeszli podobną drogę rozwoju zawodowego, a także zapewne zostali podobnie ukształtowani w domu rodzinnym. Stwierdzenie Mottego, w którym nazywa on Karola „rzemieślnikiem polskim” mimo jego niemieckiego pochodzenia, eksponuje spolonizowanie Karola i jego działania na rzecz niższych warstw społeczeństwa poznańskiego. Należy odnieść się także do pewnego mitu, jakoby Reyzner nie umiał pisać po niemiecku i wbrew wymaganiom wszystkie pisma urzędowe pisał w języku polskim. Niektóre pisma rzeczywiście sporządzał w języku polskim, lecz stwierdzić należy, że większą ich część przygotowywał w języku niemieckim, co świadczy, że język ten znał ${ }^{6}$.

Karol, po ukończeniu zapewne tylko podstawowej szkoły miejskiej, poszedł na praktykę do znanej w Poznaniu drukarni W. Decker i Sp. Tu przez

${ }^{4}$ M. Motty, Przechadzki po mieście, Poznań 1999, s. 257.

${ }^{5}$ Ibidem.

${ }^{6}$ APP, PP, 4864 Acta betreffend die Beaufsichtigung der Leihbibliothek des Karl 
sześć lat (1819-1825) uczył się zecerstwa, korzystając z dobrze wyposażonego warsztatu oraz podpatrując licznych, bardziej doświadczonych pracowników. Księgarstwo poznawał natomiast przez następne dwa lata w księgarni Juliusza Adolfa Munka lub Ernsta Siegfrieda Mittlera. Tak przygotowany do samodzielnego wykonywania zawodu 19 czerwca 1827 roku ${ }^{7}$ uzyskał koncesję na uruchomienie własnej księgarni i drukarni przy ul. Wodnej 15, jak sam często określał w anonsach prasowych, na „rogu ul. Wodnej i Garbar” lub - rzadziej, z jeszcze większą dokładnością - „w narożnym domu Wodnej i Garbarskiej ulicy na dole naprzeciw oberży hamburskiej".

\section{Założyciel pierwszej w Poznaniu polskiej wypożyczalni książek}

Działalność wydawniczo-księgarską łączył Reyzner z prowadzeniem pierwszej w Poznaniu polskiej wypożyczalni książek ${ }^{8}$, a także ze sprzedażą materiałów piśmiennych. Jak zachęcał w jednej z reklam, można było u niego „dostać papieru do pisania, atramentu, piór, ołówków, laku, tablic, rysików i innych rzeczy piśmiennych, jak też obrazków do kolorowania i pokolorowanych" ${ }^{\prime 9}$. W kolejnych anonsach informował, że prowadzi także sprzedaż „rejestrów gospodarskich, kontraktów służby i najmu” ${ }^{10}$, zapewniając, że u niego „zawsze można dostać różne rejestra gospodarskie”,11, a także „dziennik klasowy, raporta szkolne, szemata

Reyzner, tu wiele listów zachowanych w teczce personalnej.

7 AAP, NP, 3111 Verzeichniss der in Regierungsbezirk Posen vorhandenen Buchhandlungen, Kunst-Musikalien, Antiquar und Bilderhandlungen, Leihbibliotheken, Lese-Kabineten angefertigt im Februar 1851, s. 2.

8 M. Walentynowicz, op.cit., s. 50, 66.

9 "Gazeta Polska”, nr 216 z 9.12.1848, s. 4.

${ }^{10}$ Por. np. „Gazeta Polska”, nr 101 z 24.07.1848, s. 4.

11 „,Goniec Polski” 1850, nr 51, s. 224. 
ślubów” ${ }^{12}$ oraz „rycin czyli obrazów świętych różnej wielkości” ${ }^{13}$. Ten typ anonsów powtarzał Reyzner dość często w "Gońcu Polskim”, czasem uzupełniając powyższe wykazy informacjami o innych jeszcze rodzajach asortymentu, np. formularzach chrzestnych, kartach z życzeniami imieninowymi czy noworocznymi, „różnych książeczkach i zeszytach ozdobnych na gwiazdkę, jak też na nagrody do szkółek”"14, a nawet donosząc, że odebrał „co tylko w komis z nadmorskiej fabryki różne cygara tanie" ${ }^{15}$. W książce Ignacego Lipskiego Niezawodny sposób zapobieżenia kołowrotowi... (1835), w której autor zalecał leczenie przez upuszczanie krwi, znajdujemy informację, że w księgarni Reyznera nabyć można także odpowiednie do tego przyrządy. Sprzedażą tak różnych towarów Reyzner starał się bez wątpienia pozyskać klientelę dla swej księgarni i wypożyczalni oraz zwiększyć zyski. Sprzedając zróżnicowany asortyment, a także czyniąc ze swej księgarni punkt kontaktowy, np. dla poszukujących czy oferujących pracę, stancje ${ }^{16}$, nie różnił się w zasadzie niczym od innych księgarzy. Uderza natomiast, że tego typu anonse są częstsze niż te o treściach czysto księgarskich, wydawniczych, drukarskich.

Działalność wypożyczalni Reyznera opisała w opracowaniu poświęconym tym placówkom przywoływana już Maria Walentynowicz. Wskazując, że wśród istniejących wówczas w Poznaniu po 1830 roku bardziej aktywną działalność przejawiały rozwijające się wypożyczalnie polskie, jako najstarszą spośród nich wymienia właśnie tę prowadzoną przez Karola Reyznera. On sam w liście skierowanym 1 sierpnia 1842 roku do miejscowego prezydium policji pisał, że otrzymał koncesję wy-

\footnotetext{
12 „Goniec Polski” 1851, nr 208, s. 836.

${ }^{13}$ Zob. anons w: Nabożeństwo pasyjne..., Poznań 1843.

14 "Goniec Polski" 1851, nr 286, s. 1008.

15 "Goniec Polski” 1850, nr 54, s. 216.

${ }^{16}$ Zob. np. „Gazeta Polska”, nr 115 z 9.08.1848, s. 4.
} 
łącznie na prowadzenie księgarni w 1827 roku (dokładnie 19 czerwca tego roku $^{17}$ ), ale zgodnie $\mathrm{z}$ prawem „wolno było książki sprzedawać, drukować i mieć czytelnią, i dlatego o konces na czytelnią się nie starał”. Kiedy posiadanie oddzielnej koncesji stało się koniecznością prosił o czas, by mógł wydrukować katalog, co pozwoliłoby mu przygotować wniosek. Informował równocześnie, iż w czytelni zakazanych książek „żadnych nie ma do czytania” ${ }^{18}$. Z przytoczonego fragmentu dokumentu archiwalnego wynika, że mimo braku formalnej koncesji czytelnia stanowiła część firmy Reyznera od początku jej działalności. Zgodne to było z pierwotnie obowiązującymi zapisami prawnymi. Koncesja na prowadzenie księgarni upoważniała również do prowadzenia wypożyczalni, którą księgarze uważali za jeden z działów swego przedsiębiorstwa. Dopiero gdy wypożyczalnie bardzo się rozpowszechniły i przysparzały władzom pruskim wiele kłopotów, wydano zarządzenie ograniczające swobodę księgarzy. 20 czerwca 1842 roku minister spraw wewnętrznych przysłał do Dyrekcji Policji instrukcję, w któ-rej - cytuję za M. Walentynowicz - zaznaczył: „Jeżeli warunki przy założeniu księgarni zawierają jednocześnie w każdym przypadku te cechy osobowości, od których jednocześnie zależy założenie wypożyczalni, to jednak koncesja na prowadzenie księgarni nie upoważnia do uruchomienia wypożyczalni. Te ostatnie nawet w zarządzeniu z dnia 22 października 1833 r. są wyróżnione jako odrębne zakłady, dla których potrzebna jest oddzielna koncesja...". W związku z tym i Karol Reyzner otrzymał pismo nakazujące uzyskanie osobnej koncesji na prowadzenie wypożyczalni ${ }^{19}$. Kilka dni po przytoczonym wyżej liście wystosował do władz drugi, w którym stwierdzał, że po namyśle zrezygnował z tej formy działalności („,nadal czytelni trzymać nie będę”), zastrzegając so-

\footnotetext{
${ }^{17}$ APP, NP, 3111, s. 2.

${ }^{18}$ APP, PP, 4864, list z 1.08.1842, s. 26.
} 
bie jednak, „aby mu wolno było wnieść wniosek o jej założenie” ${ }^{20}$, gdy na nowo ją uruchomi.

Wypożyczanie książek rozpoczął Reyzner od małego księgozbioru, który liczył według Walentynowicz 211 dzieł opublikowanych wyłącznie w języku polskim i zawierał m.in. dużo powieści historycznych i książek popularnonaukowych. Walentynowicz oparła się na odręcznie spisanym Katalogu ksiażek wszystkich tak do sprzedania jako i czytania Ksiegarni K. Reyznera, przesłanym na polecenie władz 25 czerwca 1831 roku $^{21}$. Analiza spisu dokonana przez autora niniejszego tekstu pozwala jednak stwierdzić, że zarejestrowano w nim 242 dzieła w 378 tomach (sporą część stanowiły bowiem wydawnictwa wielotomowe). Mimo iż dokonanie pogłębionej oceny księgozbioru utrudnia niedokładny sposób sporządzenia spisu, zestaw oferowanych dzieł wydaje się znacznie bogatszy i bardziej zróżnicowany, niż wynikałoby z oceny Walentynowicz. Z reguły Reyzner podawał w spisie tylko skrócony tytuł, pomijając inne elementy pozwalające zidentyfikować dzieła. Rzadko spotkamy nazwiska autorów, a gdy już one występuja, to w zapisie typu „dzieła Niemcewicza”. Nie wiemy więc również, o które spośród utworów danego pisarza chodzi, nie możemy także stwierdzić, czy były to wydania warszawskie, krakowskie, lwowskie czy miejscowe, a więc odpowiedzieć na pytanie, skąd Reyzner sprowadzał książki do swej czytelni. Analiza spisu pozwala jednak stwierdzić, że obok utworów wspomnianego Juliana Ursyna Niemcewicza Reyzner oferował swym czytelnikom m.in. dzieła Franciszka Dmochowskiego, Jana Kochanowskiego, Adama Naruszewicza, Cypriana Godebskiego, dziesięciotomowe wydanie dzieł Ignacego Krasickiego; wiele wybitnych utworów literackich, np. Powrót posła Niemcewicza (wymieniony oddzielnie poza wspomnianymi dziełami), Fausta

\footnotetext{
${ }^{19}$ M. Walentynowicz, op.cit., s. 57-58.

${ }^{20}$ APP, PP, 4846, list z 5.08.1842, s. 28.
} 
Johanna Wolfganga Goethego, Fedrę Jeana B. Racine'a, Skapca Jeana Moliera, Fircyka w zalotach Franciszka Zabłockiego, Malwinę czyli domyślność serca Marii Czartoryskiej-Wirtemberskiej, Henryka VI na łowach Wojciecha Bogusławskiego. Obok nich znajdowały się dzieła klasyczne, takie jak Podróże Guliwera Jonathana Swifta, Przypadki Robinsona Crusoe Daniela Defoe, i te przeznaczone dla szerszych kręgów odbiorców - Wilhelm Tell oswobodziciel Szwajcarii, Pielgrzym w Dobromilu Izabeli Czartoryskiej, Pamiatka po dobrej matce Klementyny z Tańskich Hoffmanowej. Reyzner oferował klientom swojej wypożyczalni także dzieła znacznie trudniejsze, jak np. Listy Woltera i jego Semiramis oraz Raj utracony Johna Miltona; wśród wielu opracowań historycznych: sześć tomów Historii narodu polskiego Adama Naruszewicza, dwa tomy Panowania Kazimierza Jagiellończyka Jana Albertrandiego, sześciotomowe Dzieje polityczne Europy, Opis historyczny Warszawy czy trzytomowe Odkrycie Ameryki niezidentyfikowanych autorów, ale także Pisma Jana Śniadeckiego czy dwutomowe Podróże Alexandra von Humboldta. Obok tych edycji znajdujemy rzeczywiście wiele - jak to określał księgarz - „romansów”, popularnych opracowań historycznych, opisów podróży, stosunkowo dużo (14) wydań kazań, katechizmy, ponadto opracowania moralno-religijne, abecadła, książki do codziennego domowego użytku: kucharskie czy gospodarskie, np. Nowy lekarz koni, Farmacja praktyczna, Sposób rozmnożenia koniczyny.

W 1848 roku ponownie Reyzner sporządził w odręcznej formie i przedstawił władzom Katalog ksiażek polskich w Czytelni K. Reyznera ${ }^{22}$. W pozornie obszernym rękopisie (73 strony), w którym na kolejne litery alfabetu przeznaczono po kilka stron, większość stronic zostało zapełnionych tylko w części. Wydaje się, że nie był to - jak uznała Walenty-

\footnotetext{
${ }^{21}$ Ibidem, s. 2-12.

${ }^{22}$ APP, PP, 4846, s. 110-182.
} 
nowicz - wykaz książek znajdujących się w księgarni i wypożyczalni wraz z wykazem nakładów, lecz - zgodnie z tytułem nadanym mu przez Reyznera - katalog czytelni. Na opinii Walentynowicz zaważyć mógł fakt umieszczenia ceny przy większości wykazanych pozycji, co mogłoby sugerować, że były one rzeczywiście przeznaczone na sprzedaż. Wynik przeprowadzonej analizy zdaje się jednak temu przeczyć: po siedemnastu latach od sporządzenia pierwszego wykazu księgozbiór był niewiele większy, gdyż liczył 297 pozycji w przeszło 450 tomach. Rejestr z roku 1848 w niewielkim stopniu różni się od poprzedniego - powtarzają się prawie wszystkie zawarte w nim tytuły, uzupełnione pozycjami nowymi. Wahania w strukturze treściowej były minimalne: np. zmniejszeniu do 12 (z 15) uległ wykaz kazań, a do 15 (z 10) poszerzono wykaz dzieł zawierających opisy podróży. Wśród nowości odnajdujemy m.in.: dwutomowe Dzieje Królestwa Polskiego Jerzego Samuela Bandtkiego, cztery woluminy Dzieł Franciszka Karpińskiego, Dzieje Zygmunta III króla polskiego Juliana Ursyna Niemcewicza, Krótki opis historii literatury polskiej Tomasza Szumskiego, O naśladowaniu Chrystusa Tomasza á Kempis, Porzadek fizyczno-moralny, czyli naukę o należytnościach i powinnościach człowieka Hugona Kołłątaja, poemat Jagiellonida czyli połaczenie Litwy z Polska Dyzmy Bończy Tomaszewskiego, dwa utwory Seneki O pocieszeniu i $O$ życiu szczéśliwym w pokoju oraz niezidentyfikowanych autorów: Obyczaje Izraelitów, Obyczaje ludu rzymskiego, O filozofii, O Polkach uczonych, Sielanki polskie z różnych autorów. Pojawia się także w spisie Nauka czytania, co do której z bardzo dużą pewnością można powiedzieć, że ukazała się nakładem Reyznera i wydrukowana została w jego oficynie. Jego nakłady stanowiły niezauważany margines tego zasobu.

Nie może dziwić, że nie uwzględniono w tym spisie książek zakazanych, którymi niewątpliwie Reyzner handlował, skoro kilkakrotnie na- 
kładano na niego kary grzywny, a nawet aresztu ${ }^{23}$, co sugerowałoby, iż zasób czytelni i księgarni był bogatszy. Sądzę, że można się zgodzić z tą opinią w części dotyczącej księgarni, gdzie mógł przecież mieć i sprzedawać zaufanym klientom pozycje, którymi dysponował przez krótki czas, czy też takie, które w przypadku niekorzystnego wyroku mógł szybko z księgarni usunąć.

Mimo dość skromnego księgozbioru Reyzner starał się reklamować działalność wypożyczalni zarówno w prasie, jak i w anonsach umieszczanych w drukowanych przez siebie książkach. Wydaje się jednak, że kategoryczna ocena Walentynowicz, iż działalność jego wypożyczalni nakierowana była wyłącznie na biedniejsze, mniej wykształcone kręgi społeczne i miała przede wszystkim charakter oświatowy, nie jest pogłębiona. Wiele z książek wchodzących w skład księgozbioru wypożyczalni określić można jako trudne, przeznaczone do potrzeb czytelników wyrobionych, przygotowanych do ich odbioru. Nie da się oczywiście nie zauważyć pewnego założenia: gromadzenia i udostępniania książek wydanych wyłącznie w języku polskim, a wśród nich wielu historycznych, o zabarwieniu narodowym, mających za zadanie wychowywanie czytelników w duchu patriotycznym. Patrząc na znacznie bogatsze wypożyczalnie prowadzone przez innych księgarzy, które dysponowały bogatą ofertą książek zarówno polskich, jak i np. francuskojęzycznych, przedsięwzięcie prowadzone przez Reyznera nazwać należy skromnym.

\section{Działalność wydawnicza i księgarska}

Działalność wydawnicza (a także księgarska) Reyznera nie została dotychczas zbadana, podobnie jak dzieje prowadzonej przez niego wypo-

\footnotetext{
${ }^{23}$ M. Walentynowicz, op.cit., s. 51; S. Kubów, Książka Wielkiej Emigracji w Wielkopolsce (1831-1862), Wrocław 1980, s. 66-67 (Śląskie Prace Bibliologiczne i Biblioteko-
} 
życzalni. O kontaktach Reyznera w pozyskiwaniu dla niej nowości i o jej zasobach informowały - przy braku samodzielnie wydawanych katalogów - dość nieliczne anonse prasowe i wykazy dołączane do książek publikowanych przez Reyznera.

Przytaczaliśmy uprzednio przykłady anonsów pokazujących, że Reyzner dość często powiadamiał w prasie o swej pozaksięgarskiej działalności handlowej. Część z anonsów informowała o drukowanych przez niego formularzach, księgach gospodarskich, kartach, grach. Należy ocenić, że mimo iż to czynił, promocja jego działalności wydawniczej i księgarskiej, $\mathrm{w}$ tym funkcjonującej wypożyczalni, nie była tak intensywna jak tej handlowej. Czasem, podając ogólne informacje handlowe, dodawał jakby mimochodem, że poza wymienionymi drukami, materiałami piśmienniczymi w księgarni jego „dostać można różnych dzieł gospodarskich” ${ }^{24}$ lub zamieszczał krótkie informacje wydawnicze typu "także wyszło Życie Mieczysława i Bolesława z ryciną i opisem kaplicy. Pieśni weselne dla młodzieńców i drużbów $w^{\prime 25}$. Do rzadkości należały samodzielne, tak rozbudowane zawiadomienia jak to zamieszczone w numerze 164 „Gońca Polskiego” z 1851 roku:

Analiza zawartości popularnego w latach 1848-1850 dziennika poznańskiego, jakim była "Gazeta Polska”, wykazuje, że poza wspomnianymi wyżej anonsami „nieksięgarskimi” umieścił w niej Reyzner tylko (powtórzone wszakże czterokrotnie) informacje o publikowaniu kolejnych zeszytów Pieśni i piosneczek narodowych oraz wydaniu Przepowiedni Pani Lenormand. W tym drugim wypadku pozwolił sobie na rzecz dla siebie wyjątkową: umieścił krótki komentarz mający pogłębić zainteresowanie wydanym dziełkiem, wskazując, że w języku niemieckim wy-

znawcze 17).

24 "Goniec Polski” 1851, nr 224, s. 900. 
dano je już w 12 tysiącach egzemplarzy ${ }^{26}$.

Przez cały rok 1850 Reyzner nie zamieścił w „Gazecie Polskiej” żadnego ogłoszenia, mimo że znajdujemy na łamach tego dziennika wiele anonsów Walentego Stefańskiego, Jana Konstantego Żupańskiego, Napoleona Kamieńskiego, Ernsta Mittlera, Woykowskich, Księgarni Katolickiej, a nawet litografię Mariana Jaroczyńskiego. Poza „Gazetą Polską” i „Gońcem Polskim” nie zamieszczał też anonsów w przebadanych 19 innych liczących się ówczesnych gazetach i czasopismach poznańskich ani w powszechnie znanym leszczyńskim „Przyjacielu Ludu”. Potwierdza to sąd Mottego, że słabą stroną Reyznera był brak należytej energii, przedsiębiorczości, w tym także dbałości o reklamę.

Bibliografia polska XIX wieku odnotowuje trzy katalogi wydane przez Reyznera w latach 1857, 1858, jeden bez podania daty wydania oraz pochodzący z 1867 roku Katalog Księgarni katolickiej i ludowej J.Morgensterna dawniej K. Reyznera. Ani jednego z nich nie mają biblioteki poznańskie, dwa ostatnie wspomniana bibliografia lokalizuje w Bibliotece Narodowej i w Bibliotece Jagiellońskiej. Nie były to obszerne wykazy, gdyż liczyły od jednej do czterech stron ${ }^{27}$. Autorka biogramu Reyznera, Helena Magierzyna, stwierdziła, że „w roku 1831 ogłosił katalog księgarni” ${ }^{28}$. Sądzić można, że chodziło o wspomniany już rękopiśmienny spis przesłany władzom 25 czerwca 1831 roku, gdyż oddzielnego katalogu dla tego roku nie zidentyfikowano. Korzystał natomiast Reyzner z możliwości umieszczania informacji o nakładach w wydawanych przez siebie drukach. Z autopsji poznano $33 \mathrm{z}$ nich, co stanowi około $22 \%$ całej jego pro-

25 "Goniec Polski” 1851, nr 126, s. 504.

26 "Gazeta Polska" 1849, nr 8, s. 4.

${ }^{27}$ K. Estreicher, Bibliografia polska XIX stulecia, t. 15, wyd. 2, Kraków 1991, s. 176, 210.

${ }^{28}$ H. Magierzyna, Reyzner Karol Jan, w: Słownik Pracowników Książi Polskiej, Warszawa-Łódź 1972, s. 753. 
dukcji wydawniczej. W dziewięciu z nich, pochodzących z lat 1843, 1844, dwukrotnie 1847, 1848, 1856, 1857 i dwukrotnie z 1861 zamieszczono takie wykazy. Dodatkowo, w niektórych edycjach, wykorzystując wolne miejsce na ostatniej stronie tekstu, Reyzner podawał informacje o 2-3 drukach, które ostatnio opuściły jego prasę drukarską. Można więc stwierdzić, że tą drogą starał się dość systematycznie docierać do potencjalnych odbiorców.

Autor artykułu podjął trud zrekonstruowania repertuaru wydawniczego Reyznera, jednak mimo rozległej kwerendy zapewne nie udało się ustalić pełnego katalogu firmowanych przez niego nakładów oraz sporządzić bezbłędnych opisów bibliograficznych poszczególnych druków. Jak wspomniano, dużej części jego produktów nie zdołano odszukać w bibliotekach - głównie poznańskich. Poza tym część tytułów w sporządzanych przez Reyznera spisach różni się między sobą. Mamy przy tym do czynienia nie tylko ze skrótami tytułów, ale też z dość znacznymi modyfikacjami, przestawieniami kolejności słów. Taki sposób sporządzania opisów był wówczas normą, ale może sprawiać wrażenie, że mowa jest o kilku różniących się drukach, co jest trudne do stwierdzenia przy niemożności poznania ich wszystkich z autopsji, a co jednak w wyjaśnionych wypadkach rzadko znajdowało potwierdzenie.

Działalność nakładczą Reyznera tak barwnie komentował Motty:

Nie mając kapitałów, ale za to żonę znacznie wyższą od siebie i kilkoro dzieci, nie mógł się puszczać na większe przedsięwzięcia i zwróciwszy działalność swoją ku niższym sferom, był jednym z pierwszych, którzy w tym kierunku pracowali dla ludu i starał się oswajać go z drukiem. Wydawał on książki do nabożeństwa, kalendarzyki, pieśni, powiastki ludowe, czasem mu się też zdarzyło coś grubszego na świat wypuścić, i dzisiaj jeszcze znajdziesz w składach księgarskich lub po bibliotekach mnóstwo produktów z drukarni J. Reyznera. Znany był dobrze w tutejszych kołach rzemieślniczych i między mieszkańcami wsi okolicznych, którzy, osobliwie w niedziele i święta, zaspo- 
kajali u niego swoje umysłowe potrzeby. W znacznej części sam składał i sam odciskał, oddrukowywał stare rzeczy, wymyślał nowe, pracował wytrwale i pożytecznie. Szedł interes ciężko, bo zbywało na środkach, a przy tym na sprężystości należytej, ale szedł jakoś i Reyzner nie tylko trzymał się tutaj do końca życia, lecz mógł wychować dzieci swoje przyzwoicie ${ }^{29}$.

Sporządzony dla celów niniejszego opracowania spis publikacji firmowanych przez Reyznera liczy 151 pozycji. Tytułów jest mniej, ponieważ niektóre z nich osiągały kolejne wydania. Nie jest to lista pełna, gdyż rekonstrukcja dokonań wydawniczych okazuje się niemożliwa. Odnaleziono na przykład drugie i trzecie wydanie Drogi krzyżowej albo nabożeństwa do Męki Chrystusowej, ale nie udało się ustalić, kiedy ukazało się wydanie pierwsze. Mała gramatyka języka polskiego ukazała się w 1843 roku bez oznaczenia wydania, a w roku 1861 jako wydanie piąte. Nawet jeśli przyjmiemy, że to z 1843 roku było wydaniem pierwszym, nie wiemy, kiedy ukazały się wydania drugie, trzecie i czwarte. Czasem w anonsach Reyzner informował, że wydanie jest „wznowionym, poprawnym”, nie wskazując, które miejsce zajmuje w szeregu. Pomiędzy rokiem 1840, kiedy to zarejestrowano po raz pierwszy wydanie Nauki czytania, a rokiem 1861, kiedy prasy opuściło wydanie dwunaste, udało się zidentyfikować tylko pięć innych. Przytoczone przykłady pokazuja, jak znaczne mogą być jeszcze luki w sporządzonym wykazie.

Część produkcji Reyznera stanowiły druki drobne, kilku- czy kilkunastostronicowe, bardzo często o dewocyjnym charakterze (litanie, gorzkie żale, nabożeństwa majowe, pieśni), które mogły być wznawiane wielokrotnie. Niektóre tytuły pojawiały się w spisach nakładów zarówno na początku lat czterdziestych, jak i bez mała 20 lat później. Trudno stwierdzić, czy oznaczało to, że druk ten stale był w sprzedaży, bo wydano go

\footnotetext{
${ }^{29}$ M. Motty, op.cit., s. 256-257.
} 
przed laty w dużej liczbie egzemplarzy, czy też, że ukazało się jego kolejne, nieodnotowane przez wydawcę wznowienie (potwierdzałoby to spostrzeżenie Mottego o częstym wznawianiu rzeczy starszych).

Sporządzony wykaz pozwala jednak, jak można sądzić, na wyrobienie sobie zdania o charakterze prowadzonej przez Reyznera działalności wydawniczo-nakładczej. O ile analiza katalogów wypożyczalni wskazywała na oferowanie czytelnikom wielu dzieł wartościowych adresowanych do "poważnych” odbiorców, o tyle charakter zidentyfikowanych nakładów każe wyciągać wnioski przeciwne. Sądzić też można, że ewentualne odszukanie innych edycji Reyznera nie zmieni tej oceny. Z dużym prawdopodobieństwem założyć bowiem można, że odnajdziemy kolejne drobne druki o treści religijno-narodowej, a nie traktaty naukowe czy ważkie opracowania społeczno-polityczne. W produkcji wydawniczej z lat 1828- -1875 przeważały druki religijne o charakterze dewocyjnym (72 zidentyfikowane tytuły): litanie, modlitwy pojedyncze i zebrane, nabożeństwa majowe, pasyjne, gorzkie żale. Można więc śmiało uznać, że przez cały okres działalności Reyznera, a już szczególnie w drugiej jego połowie, to one stanowiły celowo wybraną specjalizację oficyny. Reyzner świadomie skierował swoją ofertę do biedniejszych i mniej wyrobionych czytelników, dla których przeznaczone też były drobne objętościowo publikacje związane z magia, zabobonem, przepowiedniami. Najbardziej znane i najmniej „wywrotowe” z kościelnego punktu widzenia, a najbardziej niebezpieczne z punktu widzenia policji były Przepowiednie Pani Lenormand (1848). Obok nich znajdujemy Józefa Chociszewskiego Kabałe czyli sztukę wróżenia kropkami (1834), obwieszczenie Skończenie świata dnia 13 czerwca 1857 (1857), Sennik zupetnie nowy (1848), Proroctwo starego Tomasza owczarza na rok 1859 i 1860 (1859) czy Wieszczbiarkę... (1864). Nawet dziełko pod tak niewinnie brzmiącym tytułem jak Ochrona od zarazy (1850) należy zaliczyć do tego nurtu, gdyż wskazywało wiernym, jak układać z liter kształt krzyża, by figura taka 
chroniła od nieszczęść w przypadku, gdy się zaraza pojawi. Widać więc, że nie tyle głęboka wiedza i wiara nakazywały Reyznerowi wydawanie tylu druków religijnych, ile nadzieja na ich zbyt. Trzeba jednak przyznać, że wśród dzieł związanych z religią odnajdujemy również poważne wydawnictwa: Institutiones Juris... Domenica Cavallariego (t. 1-2, 1834), Bibliotekę kaznodziejska, czyli zbiór wzorów mów... (1837), „Roczniki Towarzystwa do Rozkrzewiania Wiary na całej kuli ziemskiej" (z. 1-2 z lat 1840 i 1843, wydawnictwo później przejęte przez W. Stefańskiego) oraz obszerne, bo liczące blisko 150 stron na poły historyczne opracowanie Wiadomość historyczna o początku i skutkach nowego medalu wybitego na cześć Niepokalanego Poczęcia N. Panny Maryi... (1849). Należy zauważyć, że wydawania dzieł poważnych, obszernych podejmował się Reyzner właściwie tylko w pierwszym okresie swej działalności. Były wśród nich np. Czas obecny, czyli historyczny rzut oka na znakomitsze od r. 1789 do 1830 wydarzenia... Karola Strahlheima (1830), Podróże do Georgii w czasie mojej niewoli w Rosyi odbyte Stanisława Nowackiego (1833).

Do końca lat pięćdziesiątych trwała aktywność Reyznera w wydawaniu tytułów o praktycznym, gospodarsko-domowym przeznaczeniu. Opracowanie J.S. Kechta Praktyczne i poprawne hodowanie wina w ogrodach... wydane zostało w 1830 roku, a dwa lata później Zimna destylacja, albo sposób robienia wódek... Obszerne, 350-stronicowe Cukiernictwo i sztuka pieczenia..., wydane w 1840 i 1844 roku, uzupełnione zostało już znacznie skromniejszymi, jeśli chodzi o objętość, książkami: Kucharz polski... J. Wojciechowskiego (1856) oraz Kucharka polska miejska i wiejska... T. Wiśniewskiego (1858). Krótka i łatwa nauka o pszczołach $i$ ich chodowaniu (sic!)... Franciszka Hubera ukazała się w 1844 roku (wznowienie 1853). Tematykę tę uzupełniła Krótka nauka o chodowaniu (sic!) pszczół w kuszkach z podstawkami... (1857). Wydany w tym samym roku Poradnik lekarski domowy w niebezpieczeństwie życia i nagłych przypadkach... Friedricha Behrenda w sposób bardzo skrótowy, na 36 stronach, doradzał, jak się zacho- 
wać w różnych sytuacjach aż do przybycia lekarza.

Wykaz edycji ważnych i znaczących uzupełniają Karola Libelta Mowa, która miał... na obronę swoją..., Ludwika Mierosławskiego Mowa, która miat... w jezyku francuskim przed Senatem... (obie wydrukowane $\mathrm{w}$ roku 1847) i Władysława Niegolewskiego Interpelacja posła pleszewskiego... na posiedzeniu Izby poselskiej Sejmu pruskiego dnia 12 maja 1860 roku, które wyróżnić należy z uwagi na ich społeczno-polityczną treść i nazwiska autorów. W tym ostatnim wypadku, przesyłając prezydium policji egzemplarz, Reyzner z rozbrajającą szczerością informował, iż jest to ta sama rzecz, „co wyszła u Merzbacha” ${ }^{30}$. Chodziło zapewne o przekonanie władz, że jeśli taki sam druk wyszedł u Merzbacha, to nie trzeba się zastanawiać nad jego prawomyślnością. Taka praktyka dziś nas dziwi, ale z dużą pewnością można założyć, że przedruk ten bez żadnej zgody wydał z uwagi na duże nim zainteresowanie. Wspomnieć można również Sposób pewny jak można w krótkim czasie wiele pieniędzy zarobić... Heliodora Jana Stanisława Skórzewskiego (ze znanej wielkopolskiej rodziny ziemiańskiej) czy jedyny wydany przez niego - poza pieśniami i modlitwami - utwór literacki, tj. czteroaktową tragedię Albanie Antoniego Krzyżanowskiego (1850). W ostatnim okresie działalności do innych niż religijno-narodowe publikacji wrócił dwoma jeszcze tytułami, wydając w roku 1874 Mariana Długoborskiego Gospodarka włościańska w okolicy Poznania oraz Władysława Chotomskiego Sprawa budowli teatru polskiego w Poznaniu. Siedmiokrotnie wydał życiorysy, głównie świętych i błogosławionych. Jako znamienny wskażmy fakt, że praca Długoborskiego, wydana nakładem autora, ukazała się, jak zaznaczono w stopce, w „Księgarni Rolniczej i Naukowej K. Reyznera”, co zdawałoby się wskazywać na świadome podkreślenie planowanej zmiany charakteru oficyny i

\footnotetext{
${ }^{30}$ APP, PP, 4757, Acta betreffend die neuen polnischen Druckschriften, list z 10.06.1860, s. 208.
} 
odejście od dotychczasowego jej profilu.

Na marginesie należy natomiast zauważyć, że mimo deklarowanej i okazywanej postawy narodowo-patriotycznej, Reyzner nie zaangażował się w okresie Wiosny Ludów w drukowanie tak częstych wówczas odezw, oświadczeń, memoriałów, apeli. Wśród odnalezionych w zbiorach bibliotek poznańskich kilkudziesięciu egzemplarzy tylko jedną odezwę można przypisać jego warsztatowi typograficznemu.

Pozostałą część dorobku wydawniczego Reyznera stanowią dwie grupy publikacji: różnego rodzaju edycje pieśni i piosenek (od weselnych do narodowo-patriotycznych) oraz elementarze i podręczniki do nauki szkolnej, szczególnie tzw. początkowej. Wśród tych pierwszych znajdujemy najbardziej znany i najwyżej oceniony przez potomnych nakład Reyznera, który stanowiły Pieśni i piosneczki narodowe z fortepianem, wydane zeszytami w latach 1828-1829. Według badającego ten zbiór Jana Prosnaka ma on szczególne znaczenie, gdyż jest pierwszą pośród wydawanych w pierwszej połowie XIX wieku na ziemiach polskich publikacji zawierających pieśni wiejskie, miejskie, patriotyczne, towarzyskie itp. wydrukowaną łącznie z nutami. Reyzner odegrał więc tym samym pionierską rolę, ustalając na pewien czas wzory wydawania pieśni ludowych z towarzyszeniem fortepianu i "przystrojeniem” harmonicznym. W ten właśnie sposób były wydawane następne, aż do ukazania się w 1857 roku Pieśni ludu polskiego Oskara Kolberga, zbiory pieśni ludowych $^{31}$. Jak stwierdza Prosnak, w wypadku części utworów zawartych w zbiorze Reyznera zapis nutowy jest najwcześniejszym znanym w literaturze muzykologicznej. Zauważa też, że mimo wskazanych walorów trudno wydanie to uznać za spełniające wymogi wydania krytycznego, naukowego. Sam Reyzner w przedmowie zapisał, że w zastosowanym przez niego układzie pieśni porządku „żadnego nie masz, i owszem sta-

${ }^{31}$ J. Prosnak, op.cit., s. 60-61. 
rano się o to, żeby go nie było" oraz że wyboru dokonał, kierując się „upodobaniem powszechnym”, i jeśli się on komuś nie podoba, to niech wie, że „nie przeciw wydawcy, ale przeciw powszechnemu głosowi powstaje $^{\prime 32}$. Pozostał wierny temu typowi wydawnictw, publikując podobne zbiory pieśni jeszcze w latach późniejszych. Były to edycje popularne, pozbawione zapisu nutowego, zawierające obok pieśni kościelnych, religijnych i patriotycznych także np. zestawy pieśni weselnych. W obszernym ich wydaniu z 1848 roku pisał, iż drukować je będzie zeszytami, by wszystkim „ułatwić nabywanie ich jak najtaniej” i prosił równocześnie, aby każdy, kto posiada jakiekolwiek zbiory pieśni, nadsyłał je na adres księgarni w celu wykorzystania ich w kolejnych zeszytach. Widać z tego, że sposób zbierania, weryfikacji, oceny nadsyłanego materiału pozostawiał - z obecnego punktu widzenia - wiele do życzenia. Jednak aż 20 różnego rodzaju zarejestrowanych tego typu wydań pokazuje, że stanowiły one w ofercie Reyznera znaczną pozycję.

Drugą grupę ze wspomnianych wyżej publikacji stanowią „książki szkolne". Zidentyfikowano 19 wydań, ale - jak zaznaczono uprzednio nie udało się nie tylko poznać $\mathrm{z}$ autopsji wielu edycji, ale także ustalić dat ich opublikowania. W tej grupie odnajdujemy najpopularniejszą wó-wczas książkę elementarna, jaką była Nauka czytania autorstwa arcybiskupa Teofila Wolickiego, którą przerobiona, w dwóch tomach wydawał Reyzner wielokrotnie do 1854 roku, kiedy to ukazało się jej dwunaste wydanie. Był to jednak podręcznik niedostosowany już wówczas do oczekiwań i potrzeb nauczycieli. Bardzo krytyczny recenzent na łamach „Kościoła i Szkoły” stwierdził, że zupełnie nie spełnia ona celu jako książka do czytania, będąc zbiorem różnych wiadomości często niedostosowanych do poziomu rozwoju uczniów ${ }^{33}$. Opiniodawca „Szkoły Pol-

\footnotetext{
${ }^{32}$ Ibidem, s. 61.

33 „Kościół i Szkoła” (1) 1846, s. 136-137.
} 
skiej” pisał w 1849 roku: „mimo pierwszeństwa jakie jej przyznają wśród innych elementarnych nie mogę powiedzieć aby była opracowana na zasadach metodycznych", a przy tym (nie różniąc się od innych) miała według niego zawierać wiele rzeczy niestosownych, tzn. „różne powieści, historię naturalną o tworach napowietrznych, fizykę, geografię ${ }^{\prime 34}$. Wyrażając zdziwienie, że nadal się z niej korzysta, recenzenci zarazem uznawali, że taka jest po prostu konieczność, dopóki nie ma lepszej. Wydawana w latach 1841-1861 pięć razy Mała gramatyka języka polskiego doczekała się druzgocącej recenzji, gdyż stwierdzono, że „w wydaniu tego dziełka autor najwięcej rozumu pokazał w tym, że zataił nazwisko swo$\mathrm{je}^{\prime 35}$.

Podsumowując działalność wydawniczą Reyznera, powiedzmy, iż średnio w roku wydawał trzy tomy, co przy rezultatach Żupańskiego i Stefańskiego obliczonych na około 16-17 woluminów w roku, Günthera i Merzbacha na 12-13, Kamieńskiego - 11, Woykowskich - 7, Poplińskiego - 6 nie jest dorobkiem dużym ${ }^{36}$. Wyraźnie obserwujemy ewolucję realizowanej przez niego polityki wydawniczej. W pierwszych latach działalności podejmował inicjatywy bardziej zróżnicowane tematycznie, wydawał książki obszerne, przeznaczone dla szerszego kręgu odbiorców, trudniejsze w odbiorze niż te, które ukazywały się w okresie późniejszym, czyli od lat pięćdziesiątych XIX wieku. Tu wyraźnie ograniczył się do produkcji drobniejszych druków religijnych, różnego typu pieśni, litanii, modlitw, popularnej literatury biograficznej oraz szkolnych książek elementarnych. Z konsekwencją niespotykaną $u$ innych ówczesnych wydawców wielkopolskich realizował natomiast zamysł trafiania wyłącznie do Polaków, publikując przez wszystkie te lata tylko

\footnotetext{
${ }^{34}$ Por. Rozbiór książek elementarnych, „Szkoła Polska” (1) 1849, s. 121-123, 181-187.

35 "Orędownik Naukowy” 1844, nr 11, s. 87-88.

${ }^{36}$ Obliczenia własne autora, por. A. Jazdon, Polski ruch wydawniczy w Wielkim Księstwie Poznańskim w latach 1831-1862, Warszawa-Poznań 1990.
} 
jedną książkę w języku niemieckim. Był to przy tym podręcznik języka niemieckiego, a więc także, można założyć, publikacja przeznaczona dla dzieci polskich zmuszonych do nauki tego języka.

Ponieważ znaczna część produkcji wydawniczej Reyznera należała do obiegu jarmarcznego, publikowane przez niego druki bardzo rzadko były przedmiotem oceny, omówień czy recenzji. Poza wspomnianymi wyżej przytoczyć można jeszcze jedną właściwie tylko ówczesną opinię: pierwszy zeszyt „Roczników Towarzystwa do Rozszerzania Wiary na całej kuli ziemskiej” (1840) odnotował redaktor „Przyjaciela Ludu”, stwierdzając, że wydany został na papierze pięknym, drukiem wyraź$n^{3}{ }^{37}$. W wypadku Reyznera stanowi to rzadkość, gdyż do tego druku można przyrównać właściwie tylko równie poprawne pod względem poligraficzno--edytorskim wydanie Institutionis juris canonici... Domenica Cavallariego (1834). Większość nakładów Reyznera to edycje brzydkie, drukowane na grubym, szarym papierze (jak sam nazywał - „ordynarnym”), czcionką stosunkowo dużą, odbitą niewyraźnie, co wynikało zarówno z niskiej jakości papieru, jak i z zużytego garnituru czcionek, oprawione $\mathrm{w}$ bardzo cienki papier. Firmowane przez niego tytuły rzadko były ilustrowane, a te zawierające ilustracje, anonsowane dzięki temu jako „piękne”, też pozostawiają wiele do życzenia. Trudno jego produkty porównywać pod jakimkolwiek względem z edycjami wychodzącymi nie tylko z drukarni Michała Zoerna, ale nawet z drukarni Walentego Stefańskiego czy Napoleona Kamieńskiego. Śledzenie anonsów informujących o wydaniu kolejnych arkuszy Pieśni i piosneczek narodowych w roku 1848 pozwala określić, że druk każdego z nich (w nieznanym, ale zapewne niezbyt wielkim nakładzie) zajmował w najlepszym wypadku około 8-9 dni ${ }^{38}$. Oznacza to, że Reyzner dysponował chyba jedną sto-

\footnotetext{
37 „Przyjaciel Ludu” (6) 1840, nr 46, s. 368.

${ }^{38}$ Por. „Goniec Polski” 1848, nr 26 (21.04), nr 62 (6.06), nr 89 (10.07).
} 
sunkowo małą maszyną pozwalającą zadrukowywać niezbyt duże arkusze papieru (większość jego druków stanowią książki złożone z małoformatowych arkuszy). Tłumaczy to, dlaczego - poza swoimi nakładami - nie drukował dla innych wydawców. Wprawdzie we wspomnianych anonsach czytamy, iż przyjmował do wykonania prace drukarskie, sądzić jednak można, że chodziło raczej o drukowanie - mówiąc dzisiejszym językiem - różnego rodzaju akcydensów, a nie poważnych wydawnictw. Akcydensów takich jak księgi, wykazy, formularze, rubrykatory - jak pamiętamy - niemało sprzedawał w swej księgarni.

Wzorem innych wydawców starał się Reyzner drukować partie niektórych edycji na papierze „pięknym”, część wyposażając w ilustracje. Naukę do czytania z 12 obrazkami... (1857) kupować można było jako wydanie „czarne” po 1 złp. lub „malowane” o 15 grp. droższe. Być może założyć powinniśmy, że drukowanie wielu wydań dużą czcionką spowodowane było przewidywanym kręgiem odbiorców (osoby starsze, słabo czytające) i warunkami użytkowania (złe oświetlenie w domu czy w kościele). Zapewne na decyzję o druku mało estetycznym, ale tanim wpływała chęć obniżenia ceny publikacji. Nakłady Reyznera rzeczywiście nie były zbyt drogie. Analiza cen 56 spośród jego wytworów pozwala stwierdzić, że cenę jednego arkusza kalkulował na poziomie 6-9 grp. To cena porównywalna ze średnią wyliczoną dla wydawców poznańskich tego okresu, a w niektórych wypadkach niższa ${ }^{39}$. Ceny były, rzecz jasna, zróżnicowane: Naukę czytania skalkulował Reyzner na 5 grp., ale Pieśni i piosneczki narodowe z towarzyszeniem fortepianu (1828-1829), z racji tego, że zawierały zapis nutowy, już na 1,2 złp. za arkusz.

Chcąc zachęcić do kupna, Reyzner wydawał również niektóre edycje arkuszami, aby zainteresowani mogli łatwiej je nabywać. Stosował też sprzedaż półhurtową: kilkakrotnie, jak np. w wypadku Modlitw krótko

\footnotetext{
${ }^{39}$ Por. A. Jazdon, op.cit., s. 199, gdzie wyliczono ją na 10 grp. za arkusz.
} 
zebranych... (1844), informował, że "dla biorących 25 egzemplarzy" cena będzie niższa o 15 grp. niż przy zakupach pojedynczych. Widać na tych przykładach, że nie odbiegając w tym względzie od innych, stosował powszechne wówczas praktyki handlowe.

Brakuje jakichkolwiek informacji na temat wysokości nakładów publikacji Reyznera. Przytoczony anons zdaje się sugerować niemały nakład tego tytułu. Nakłady mogły rzeczywiście być wysokie przy drukach religijnych, tanich z uwagi na skąpą objętość (średnia objętość druków w tej grupie wynosiła 32 strony) i standard wydania. Raz tylko w „Przyjacielu Ludu” we wspomnianym anonsie „Roczników Towarzystwa...” napisano, że ponieważ wydane zostały w „niezbyt wielkiej liczbie” egzemplarzy, każdy, kto chce dostawać kolejne tomy, winien się zapisać, a „wszystkie księgarnie krajowe i zagraniczne przyjmują przedpłatę ${ }^{40}$.

Rzadko również Reyzner informował o powodach podjęcia określonej inicjatywy wydawniczej. We wstępie do Kazań i mów pogrzebowych (1862) napisano, że do ich edycji zachęcił wydawców zupełny brak zbioru mów pogrzebowych odnoszących się do różnych sytuacji, co sprawia, że wielu księży, którym brakuje czasu na przygotowanie kazania, jest bezradnych w momencie nagłej konieczności ich wygłaszania. Gotowe teksty miały właśnie uwolnić od konieczności przygotowywania się, stanowiąc dogodny wzór do powielenia lub przerobienia. Była to formuła niemal standardowo używana $\mathrm{w}$ tego typu publikacjach. Wydając natomiast tłumaczenie niemieckiej Biblioteki kaznodziejskiej (1837), Reyzner podkreślał, że chce w ten sposób uchronić zawarte w niej kazania od zapomnienia i zniszczenia oraz dać współczesnym przykłady mów wybitnych. Żywoty świętych wydawał pojedynczo, tak by każdy „mógł dostać swego patrona lub patronkę $e^{41}$, a poznając jego biografię, zyskać podstawo-

\footnotetext{
${ }^{40}$ Por. przypis 36.

${ }^{41}$ Anons w: Arcybractwo Najdroższej Krwi..., Poznań 1847.
} 
wą wiedzę o nim i wzór do naśladowania. W przedmowie do Cukiernictwa... (1840) autor, a nie wydawca, wskazywał, że chce, aby dzięki dziełu wszyscy nieumiejący dotąd piec, mogli samodzielnie wypieki wykonywać.

Część przytoczonych uwag pochodziła od samych autorów. Reyzner jako wydawca żadnych innych informacji o przyświecających mu celach, powodach wydania, przeznaczeniu książek czy ich zaletach nie podawał. Trzeba przyjąć, że zakładał, iż charakter większości z publikowanych druków nie wymaga słów zachęty, wyjaśniania czy usprawiedliwiania celu podjętego wysiłku. Przedrukowując tytuły starsze, nie myślał o prawach autorskich, finansowych, a liczył na "sprawdzone” nimi zainteresowanie. Tytuł Krótkiego nabożeństwa do NP. Maryi, w obrazie Kościoła parafialnego Lubińskiej Górki (1847) uzupełnił dopiskiem: „Dawniej nieco wydrukowana, a teraz ku użytkowi wiernych z niektóremi przydatkami, dla wygody pewnych parafii" ponownie wydana. Zgoda władz duchownych na wydanie tej książeczki pochodziła z 1811 roku.

Przytoczony wyżej anons informujący, że przedpłatę na wydane dzieło przyjmują „wszystkie księgarnie krajowe i zagraniczne”, dowodzi powiązań przedsiębiorstwa Reyznera z innymi firmami. Należy więc zadać pytanie, czy i ewentualnie w jakim stopniu ofertę księgarni Reyznera wzbogacały tytuły innych nakładców. Poszukiwanie informacji na ten temat przyniosło słabe rezultaty. Kwerenda prasowa nie wykazała, aby wzorem innych księgarzy - dla których było to dość rutynowe działanie - Reyzner informował o otrzymaniu nowych przesyłek krajowych i zagranicznych. $W$ informacjach dołączanych do wydawanych publikacji obok stosunkowo częstych anonsów własnych produktów tylko raz, w druku Kometa na rok 1856, umieścił wykaz sprzedawanych nakładów obcych, kończący się zapewnieniem, że zawsze u niego można dostać „wszystkich dzieł polskich i kazań, które tylko gdzie wyszły i wychodzą” oraz że także do „czytelni polskiej ciągle najnowsze dzieła sprowa- 
dza". Spis ten zawierał dziesięć pozycji, z których aż pięć stanowiły utwory Władysława Syrokomli: Gawędy i rymy ulotne, Zgon Acerna, Baka odrodzony, Wielki Czwartek, Janko Cmentarnik. Kolejne to Apolla Nałęcza Korzeniowskiego Komedya, ks. Augusta Lipnickiego Życie Św. Jadwigi oraz Ksiażeczka do nabożeństwa Św. Jadwigi, a także Podróż naokoło świata... oraz Od bieguna do bieguna Jakuba Arago. Poza ostatnia, którą można identyfikować jako wydaną w Warszawie przez Merzbacha w 1846 roku, wszystkie opublikował w roku 1856 Samuel Orgelbrand w Wilnie. Musiał więc Reyzner mieć z tym wydawcą kontakt.

W celu pozyskania nowości dla swojej wypożyczalni Reyzner utrzymywał kontakty z księgarnią Friedleina w Krakowie, o czym świadczy fakt, iż w 1837 roku Flotwell kazał pociągnąć go do odpowiedzialności z powodu znalezienia 25 druków krakowskich z rachunkiem tejże księgarni $^{42}$. Czy inne księgarnie sprzedawały jego produkty? Jeśli chodzi o poznańskie księgarnie, wiadomo, że kłopoty miał Kamieński sprzedający jego Pieśni i piosneczkit3.

\section{Konflikty z władzami}

Charakter prowadzonej działalności narażał Reyznera na dość częste konflikty z władzami. Rozprowadzać miał pisma Towarzystwa Demokratycznego Polskiego z Paryża ${ }^{44}$. Przypomnijmy stwierdzenie Stefana Kubowa, że sprzedawał i inne druki objęte zakazem rozpowszechniania, choć w małym stopniu informacje te znajdują konkretne potwierdzenia, np. w protokołach policyjnych. Często oskarżano go o rozpowszechnianie polskich ulotek i narodowo-religijnych pieśni. Poza wspomnianymi

\footnotetext{
${ }^{42}$ Por. M. Walentynowicz, op.cit., s. 51.

${ }^{43}$ M. Rajch, Cenzura pruska w Wielkopolsce w latach 1848-1918, Poznań 2004, s. 115$-116$.

${ }^{44}$ J. Kozłowski, op.cit., s. 621-622.
} 
wyżej wiadomo, że 12 lipca 1848 roku zarekwirowano mu Pieśni i piosneczki narodowe jako mające podniecać do buntu. Zwrócono mu je jednak wyrokiem sądu z 24 września 1849 roku ${ }^{45}$. Warto przy tej okazji zwrócić uwage na dość znamienny anons umieszczony w "Gazecie Polskiej” w sierpniu 1848 roku. Wskazuje on pewien sposób wykorzystywania tych niesprzyjających okoliczności. Reyzner donosił w nim, że wyszedł już z więzienia (po odbyciu kary czterech tygodni aresztu), i informował, że można w jego księgarni dostać różne rejestry gospodarskie, kontrakty itd. Konkludował: „Spodziewam się, że publiczność Polska zechce swego rodaka wesprzeć zakupywaniem tychże $\mathrm{e}^{\prime 46}$.

Kolejne podejrzenie padło - tym razem $\mathrm{z}$ powodu treści natury politycznej, które same z siebie miałyby niejako stanowić zagrożenie dla panującego porządku prawnego - na drobną książeczkę Przepowiednie Pani Lenormand. Tym razem nie doszło do poważniejszych oskarżeń, aresztu czy konfiskaty nakładu ${ }^{47}$. W 1855 roku skonfiskowano i zniszczono wydaną przez Reyznera Modlitwę Polaków do Boga z uwagi na zawartą w niej prośbę o pobłogosławienie i przywrócenie dziedzictwa przodków, złączenie „w jedno ciało rozproszone plemię nasze polskie”. Uznano, że podżega ona mieszkańców państwa do wzajemnej nienawiści ${ }^{48}$. Mimo podejrzeń, dokonywanych rewizji, kilkumiesięcznego śledztwa w sprawie wydawanych publikacji, kilkakrotnego ukarania grzywnami sięgającymi 50 talarów Reyzner nie zmienił charakteru działalności, zarówno księgarni, jak i wypożyczalni, co pozwoliło policji kilka lat później, w roku 1857 stwierdzić, że trzej księgarze: Żupański, Reyzner i Kamieński

${ }^{45}$ APP, PP, 4864, list z 23.10.1849, s. 46.

46 "Gazeta Polska”, nr 115 z 9.08.1848, s. 4.

${ }^{47}$ APP, PP, 4747 Acta betreffend die Beschlagnahme der Druckschrift Przepowiednia Pani Lenormand.

${ }^{48}$ G. Kucharczyk, Cenzura pruska w Wielkopolsce w czasach zaborów 1815-1914, Poznań 2001, s. 328-329. 
ustawicznie przekraczają przepisy prawne policji i są stale oskarżani o rozpowszechnianie i wydawanie zakazanych druków ${ }^{49}$. Mimo iż uznano, że wszyscy trzej dopuścili się czynu karygodnego, zrezygnowano z zastosowania środka ostatecznego, jakim byłoby odebranie im koncesji. Zdecydowano jedynie o udzieleniu protokolarnego ostrzeżenia, że ponowne popełnienie przestępstwa może skutkować utratą zgody na prowadzenie działalności księgarskiej ${ }^{50}$.

Dość szczegółowo opisany został przypadek oceny drugiego zeszytu Pieśni narodowo-religijnych, które Reyzner planował wydać w 1861 roku ${ }^{51}$. Analiza zakwestionowanych fragmentów ujawnia sposób patrzenia władz na tego typu wydawnictwa. Z kolei - jak przytacza Kucharczyk po konfiskacie w tym samym roku Pieśni do Matki Bożej Reyzner adresował do prezydium policji list, w którym, prosząc o wydanie zabranych mu pieśni jako niezawierających nic przeciwko rządowi ani religii, pisał, że "te same pieśni drukuje i sprzedaje drukarz S. Pawicki i niepodobna, aby się to działo bez wiedzy" policji. Konkludował dalej, że jeśli wolno Pawickiemu, to i on winien móc je sprzedawać. Trudno stwierdzić, czy miało to bezpośredni wpływ na decyzje władz, ale w krótkim czasie Pawicki został poddany represjom, w tym skonfiskowano jego nakłady ${ }^{52}$. Zadziwiające jest powtarzanie się tego typu tłumaczeń, gdyż założyć trzeba, iż Reyzner powinien mieć świadomość, jakie mogą one przynieść skutki.

Karol Reyzner jako wydawca, księgarz, drukarz i właściciel wypożyczalni w porównaniu z wieloma konkurentami działającymi w tym sa-

${ }^{49}$ M. Walentynowicz, op.cit., s. 51.

${ }^{50}$ M. Rajch, op.cit., s. 113-114.

${ }^{51}$ Por. G. Kucharczyk, op.cit., s. 331-334. Zob. też APP, PP, 4846, s. 249, na które nie powołuje się G. Kucharczyk, a wskazujące, że sprawa ciągnęła się do maja następnego roku, kiedy ponownie przytacza się zakwestionowane treści.

${ }^{52}$ G. Kucharczyk, op.cit., s. 334. 
mym czasie na rynku poznańskim nie wyróżnił się niczym specjalnym. Jednak w świetle dokonanych badań można wyżej - niż czyniono to dotychczas - ocenić rolę prowadzonej przez niego wypożyczalni, której księgozbiór nie był tylko przeznaczony dla zaspokojenia prostych, niewyszukanych potrzeb słabo wyrobionych czytelników, ale służył też wyrobionym literacko odbiorcom. Wyraźnie dostrzegamy krystalizowanie się jego zainteresowań wydawniczych, koncentrację wysiłków na dostarczeniu czytelnikom literatury religijnej, a także narodowo-patriotycznej przez publikowanie zbiorów czy pojedynczych pieśni, częstokroć poszukiwanych i rekwirowanych przez policję. O tym, kto miał być jej odbiorca, przekonują druki tanie, o niskim standardzie edytorskim, dostarczające czytelnikom nieskomplikowanych, prostych, zrozumiałych treści. Jednoznaczna ocena działalności Reyznera wydawać się może dość trudna. Przywołajmy dwie skrajne opinie. Wielokrotnie wspominana Walentynowicz napisała: „Drukarnia nakładowa Reyznera nie miała większego znaczenia, gdyż wydawał on głównie pieśni religijne i druki o miernej wartości" ${ }^{\prime 53}$. Późniejszy badacz tego okresu, Franciszek Paprocki - omawiając przejawy i efekty legalnej walki prowadzonej przez Wielkopolan napisze natomiast, że „nastąpiła wyraźna poprawa na polu rozpowszechniania literatury popularnej, historycznej i religijno-obyczajowej”. Do tej akcji, która przyniosła według Paprockiego tak pożądane i wartościowe rezultaty, „włączyły się mniej lub więcej wszystkie drukarnie i księgarnie polskie. Z księgarzy przodowali: Walenty Stefański, Jan Konstanty Żupański i Karol Reyzner" ${ }^{\prime \prime 54}$.

Można więc w podsumowaniu zapytać, czy warto dziś zajmować się osobą której działalności nie daje się porównać z osiągnięciami najwybitniejszych wydawców i księgarzy tego okresu: Żupańskiego, Stefańskiego,

\footnotetext{
${ }^{53}$ M. Walentynowicz, op.cit., s. 51.

${ }^{54}$ F. Paprocki, Wielkie Księstwo Poznańskie w okresie rządów Flottwella (1830-1841),
} 
Kamieńskiego? Bez wątpienia właśnie oni nadawali ton i wytyczali kierunek działalności pozostałym. Wydane przez nich edycje, ich inicjatywy wydawniczo-księgarskie i osiągnięcia poligraficzne zaspokajały wiele potrzeb ówczesnych odbiorów i dziś są szeroko znane. Stwierdzić jednak należy, że obok tych wybitnych w ówczesnym Poznaniu działali m.in. Adolf Munk, Julian Heine, bracia Scherkowie, Ernest Mittler i wielu innych. Wśród nich także przez pięćdziesiąt lat Karol Reyzner. Fakt tak długiego, nieprzerwanego funkcjonowania w jednym mieście, ba, w jednym miejscu, pozwala stwierdzić, że jego działania trafiały na podatny grunt, były oczekiwane, miały stałych odbiorców. Był niezbędny określonej grupie czytelników, tak jak inni potrzebowali edycji Tytusa Działyńskiego czy Jana Konstantego Żupańskiego. Konieczne wydaje się więc uzupełnianie obrazu ówczesnego rynku książki przypomnieniem także osób pokroju Reyznera. Brak zapotrzebowania na jego usługi zmusiłby go do zmiany profesji, nie pozwoliłby na utrzymanie rodziny i kształcenie dzieci. Niewiele wprawdzie wiemy o tej stronie życia rodziny Reyznera, ale warto przytoczyć jeszcze jedno stwierdzenie Mottego, który, pisząc o jego licznym potomstwie, wspominał: „Z owych dzieci znałem tylko najstarszego, zdolnego i roztropnego chłopca, chociaż fizjonomii nieponętnej, który złożywszy maturę w gimnazjum Marii Magdaleny, przerąbał się przez uniwersytet jako pedagog", lecz niestety wkrótce po odbyciu rocznej próby nauczycielskiej w szkole realnej umarł na sucho$\mathrm{ty}^{55}$. Fakt, iż Reyzner łożył na drogie studia syna, dowodzi, że - sam niewykształcony - miał świadomość wagi wykształcenia.

Karol Reyzner zaprzestał działalności około roku 1875, przeniósł się do nieodległego Zaniemyśla, gdzie zmarł 1 października 1887 roku i trzy dni później został pochowany na tamtejszym cmentarzu, o czym zawia-

Poznań 1970, s. 275.

${ }^{55}$ M. Motty, op.cit., s. 256-257. 
domili w nekrologu córka oraz syn ${ }^{56}$.

\title{
ARTUR JAZDON \\ Karol Reyzner (1803-1887) - Poznań-based publisher and printer
}

\begin{abstract}
The book market in Poznan at the turn of the 1920s and the 1930s got a particular boost and encouragement. Following a temporary softening of the strict policy of the German authorities towards the Poles, Polish lending libraries and bookshops publishing in Polish and for the Poles began to crop up. The press market, publishing both local newspapers and journals, enjoyed a particular development. Karol Reyzner was a lesser known publisher and undoubtedly stayed in the shade of more eminent and prominent figures such as Walenty Stefański, Jan K. Żupański, Napoleon Kamieński, Antoni Popliński and Ludwik Merzbach. His influence upon the local book market was far less intensive than that of the above mentioned publishers as his publications were not that numerous or important. However, K. Reyzner managed to survive on the market for as long as half a century, i.e. for a much longer period than many other prominent local Polish publishers of the time. Publishing primarily books for less educated people and specializing in publications with no scientific or literary aspirations, simple and cheap judging from the editorial standards, he nevertheless carried out an important social function. The present article discusses the history of Reyzner's printing office and its publishing output, additionally outlining the role of the lending library attached to the printing office - the first one managed by a Pole and targeted at the local Polish population. The analysis of the still existing catalogues of the library indicates that, unlike the publishing activity of the firm, the lending library addressed much more cultured and refined reader, which is manifested by the content of the collection that included many accomplished works written by prominent authors or researchers of the time.
\end{abstract}

${ }^{56}$ „Dziennik Poznański” 1887, nr 226 (4.10), s. 5. 
KEY WORDS: Wielkopolska (Greater Poland) - 19th c., printing industry, publishing movement, history - 19th c., lending libraries, readership, book lending - 19th c. 